\title{
A SPORTESZKÖZÖK PIACÁNAK HELYZETE
}

\author{
Harangi-Rákos Mónika - Nagy Adrián Szilárd - Pfau Christa - \\ Müller Anetta - Szabados György Norbert - Bácsné Bába Éva
}

\section{Összefoglalás}

Cikkünk célja a sportágak fejlödésének történelmi áttekintése mellett vizsgálni a sportszerek és sporteszközök gyártásának változásait. Ahogy az egyes sportágak szabályrendszerei kialakultak a 19. századtól fogva, úgy egyre több sportág esetében jelentek meg olyan szabálykönyvek és szabványok, amelyek az adott aktivitás müveléséhez szükséges eszközökre vonatkoztak. A sportok elterjedését gazdasági, társadalmi és családi körülmények is befolyásolják - éppúgy, mint az egyének sportolás iránti nyitottságát. A sportszerek gyártása és kereskedelme a globálisan egyre jelentösebbé váló sportgazdaság és sportipar egyre tekintélyesebb részét adja. Az Európai Uniós sporteszköz-és sportszerpiac hagyományosan nagy múltra tekint vissza. Az egyes sportágak jelentösége tagállamonként eltérö, emellett az is látható a statisztikai adatközlések alapján, hogy a sportszerek kivitele és behozatala között szerkezeti különbségek mutathatók ki. Az Európai Unió kivitele szempontjából a csónakok és vizisporteszközök kivitele a legjelentösebb: mintegy kétharmadnyi részesedésével dominál, míg a behozatal esetében ilyen erös jelenléttel egyik termékkör sem bir.

Kulcsszavak: sport, sporteszköz, fogyasztás, Európai Unió, társadalom JEL: $L 67, L 83$ 


\title{
SITUATION OF THE SPORTS EQUIPMENT MARKET
}

\begin{abstract}
The aim of our article is to present the historical development of the different sports and to analyse the changes of the production of the different sports equipments. As the rules and regulations of the different sports have been indited since the $19^{\text {th }}$ century, the rulebooks of several sports have been also formulated and published. In these rulebooks the exact and strict standards have been created in order to regulate the characteristics of the sports equipments. Economic, social, and familiar circumstances also have effect on the spread of the different sports and on the sporting activity of the people. The production and commerce of the sports equipments represents an important part of the globally increasing sports economics and sports industry. The sports equipments market of the European Union has a great tradition. The importance of the different sports in the Member States of the European Union is distinct and some important sectoral differences can be described between the import and the export of the sports equipments on the level of the European Union. The boats and the water sports tools represent about two third of the EU-level sports equipments export. In case of the sports equipments import we cannot find this kind of centralization.
\end{abstract}

Keywords: sports, sports equipment, consumption, European Union, society JEL: L67, L83 


\section{Bevezetés}

A sport jelentős szerkezeti átalakuláson ment keresztül az elmúlt években. A fejlett országokban a sportesemények megtekintésében a helyszíni nézők jelentősége csökkent a különböző közvetítések fogyasztóihoz képest, a látványos sporttartalmak egyre gyakrabban jelennek meg a televíziós és egyéb sugárzásokban (James et al., 2018). Bácsné et al. (2018) vizsgálta, hogy nagyságrendileg milyen gyakorisággal látogatják a különféle sporteseményeket $(\mathrm{n}=800)$. A megkérdezettek 39,4\%-a viszonylag ritkán, míg 26,13\%-a soha nem látogat ki sporteseményekre. Ezzel szemben mindössze 17,1\%-uk, amikor csak teheti, élőben szurkol, és 17,4 \%-uk pedig időközönként látogat sporteseményeket.

A sport vizsgálatát három lehetséges nézőpontból kezdhetjük el. A sportok egyfelől vizsgálhatóak a játék egy formájaként, vagyis annak a szabályrendszernek az öszszességeként, amelynek keretei között az adott játék művelhető. Másrészt a sport vizsgálható úgy is, mint egy szolgáltatás. Ebben az esetben a sport célja egy-egy csoport érdekeinek kielégítése lesz majd. Természetesen az érintett érdekek és célok igen sokfélék lehetnek, amelyek között a hadászat (Dajnoki et al., 2019) és a politika mellett az oktatás is megjelenik motiválóként. Emellett ennél a vizsgálati aspektusnál ki kell emelni az egyének törekvését egészségük megőrzése, egyéni jóllétük garantálása irányába. A sport harmadik lehetséges vizsgálati nézőpontja a művelésükhöz szükséges létesítmények és eszközök elemzése. Ennek során elsődlegesen azokat az eszközöket és létesítményeket elemzik, amelyek nélkül az adott sportág nem volna művelhető (Hardy, 1986). Cikkünk célja elsősorban az, hogy a harmadikként említett eszközés létesítményelemzések lefolytatásához biztosítson támogatást.

A sporttermékek körében további csoportokat is kialakíthatunk. Az első csoportba a sportolók számára készülő termékek kerülhetnek, amelyek között találhatóak játékok, felszerelések és mezek, utasításokat és segédleteket tartalmazó kiadványok, létesítmények és klubok is. A második csoportba azok a termékek kerülhetnek, amelyek a nézők számára készültek. Ide tartoznak - egyebek mellett - a sportmédia különböző elektronikai eszközei is. A harmadik csoportba pedig az úgynevezett kapcsolódó termékek kerülhetnek. Itt található meg minden olyan termék, amely nem szorosan véve kapcsolódik a sport műveléséhez vagy nézéséhez. Jó példa a csoport tartalmára a különböző sporteseményekhez kötődő catering termékek köre (Vamplew, 2018). 


\section{Anyag és módszer}

A sport társadalmi, egészségügyi és nemzetgazdasági szerepével a tanulmányok és szakcikkek folyamatosan növekvő számban foglalkoznak (Bácsné et al., 2019). A témakör jelentősége napjainkra nem lehet kérdéses: a nyugati civilizáció életmódjában a szellemi munkakörök térnyerésével egyre nagyobb szerep hárul az egészség fenntartására, így a sportokra is. Ezt tükrözi a témakör iránti egyre jelentősebb kutatói érdeklődés.

A cikk készítése során számos adatbázisból és cikkgyüjteményből dolgoztunk. A feldolgozott szakirodalmak részint a Google Scholar, avagy Google Tudós, részint a MATARKA, részint az AGECONSEARCH, részint pedig az EconBiz.de keresőoldalakról származnak. A feldolgozott statisztikai adatközlések mindenek előtt az Európai Unió és egyes tagállamai, illetve egyes érintett szervezetek, cégek vonatkozó adatait ölelik fel, amelyek feldolgozása a kutatási etikai és módszertani normák teljes mértékü tiszteletben tartása mellett történt.

\section{A sportszergyártás történelmi fejlődése}

A sport széles körü elterjedése a nyugati társadalmakban az 1960-as évektől vette kezdetét. Ebben az időszakban a gazdasági fellendülés már több szabadidőt tett elérhetővé az emberek számára, akik ennek eltöltésére - egyéb lehetőségek mellett - a sportot is igen nagy számban választották. Erre az időszakra tehető, hogy a sportszerek, sportcikkek, sporteszközök és sportruházatok gyártása - a sportgazdaság számos egyéb szegmensével egyetemben - egyre nagyobb jelentőségre tett szert, az elmúlt évtizedek során tapasztalt bővülésnek köszönhetően pedig napjainkra a globális gazdaság egyik jelentős szegmensévé válhatott (Gyömörei, 2015). A különböző sportágak elterjedésében számos társadalmi osztály is szerepet játszott - elsősorban azt befolyásolva, hogy az adott sportágat kik müvelik, kik foglalkoznak azzal. Ennek megfelelően a sportágak egy része évtizedek, akár évszázadok fejlődése során populárissá vált, míg más sportok megőrizték exkluzivitásukat, arisztokratikus jellegüket. Az első csoportra remek példa a labdarúgás, amely az elit kedvelt sportágából kiindulva válhatott napjaink - társadalmi osztálytól függetlenül - kimagaslóan népszerü sportágává. A második, az elzártságát és exkluzivitását máig jól őrző sportágak közül ki lehet emelni a golfot, a teniszt vagy a vitorlázást, amelyet jellemzően szigorú tagsági rendszerrel bíró klubokban gyakorolhatnak kedvelőik (Bourdieu, 1978). A sportok populáris vagy exkluzív jellege természetesen az ahhoz köthető sportcikkek, sporteszközök vagy sportruházatok árával is komoly összefüggést mutat.

Számos olyan sportág, amely ma is ismert és játszott, eredetileg a 19. század során alakult ki. Erre az időszakra tehető ugyanis, hogy az egykori szabályzás nélküli népi 
játékok megjelentek a felsőbb osztályok iskolarendszerü képzéseiben is, azonban már egy egészen új, formalizált rend szerint. Az átalakított játékok megjelenése az oktatásban ahhoz a célhoz kötődött, hogy a diákok fizikai fejlődését is támogassa az iskola, azonban minderre rendezett körülmények között, meghatározott szabályok betartásával kerülhessen sor. A 19. században tehát a formalizált sportok művelésében arisztokrata családok férfitagjai vehettek részt (Dunning, 2002). Elsőként Magyarországon is olyan sportágak jelentek meg arisztokrata közvetítéssel, amelyek költséges mivoltuk miatt eleve kizárólag a nemesi családok számára voltak elérhetőek. Ilyen sportok voltak például a falkavadászat vagy a lovaglás, amelyek kimagasló költségigényt támasztottak művelőikkel szemben, de a vívás vagy az evezés is elsősorban a nemesség számára volt elérhető. Ehhez képest a század végén kialakuló és egyre népszerübbé váló atlétika sokkal szélesebb körben elérhető, ráadásul eleve a versengésre kialakított szabályrendszere könnyebben követhetővé is tette azt (Detre, 2013). Mindez a különböző sporteszközök, sportcikkek és sportruházat szükségessége és fogyasztása szempontjából is lényeges. Látható, hogy az eleinte kialakult elit sportágak költségés eszközigénye igen nagy. A falkavadászathoz vagy a lovagláshoz szükséges eszközök beszerzése is igen költséges, a további kiadások, így különösen az adott sportág müveléséhez szükséges állatok gondozása olyan összegü kiadásokat tesznek szükségessé, amelyeket csak a leggazdagabb családok vállalhatnak fel. Ehhez képest az atlétika müveléséhez sokkal kevesebb - és olcsóbb - sporteszközre van szükség, amelyek beszerzése nem állít olyan mértékű kiadást a különböző sportok művelői felé, mint az arisztokrata sportoké. Érdekesség, hogy a sportolási és közlekedési célra egyaránt használható kerékpárok gyártását és kereskedelmét már igen korán mérni kezdték NagyBritanniában, és megállapították, hogy a kerékpár mint sporteszköz gyártása és kereskedelme egyre nagyobb gazdasági hatással bírt. Az 1890-es években, a biztonsági kerékpárok elterjedésének idején például csak Londonban, Birminghamben, Coventryben és Nottinghamben 850 kerékpárgyártó vállalkozás müködött, teljesítményük pedig évről évre egyre jelentősebb mértékben emelkedett (Harrison, 1969). A biztonság egyre fontosabb szerepet kezdett játszani (Bujdosó-Györki, 2011).

\section{A sportszerek fogyasztása}

Azok a cikkek, amelyeket a fogyasztók sportolási tevékenységük támogatása, művelése érdekében vásárolnak, vagyis a sporteszközök normáljószágnak, azon belül pedig luxusjószágnak minősülnek. Ennek megfelelően a sportoláshoz használt eszközök fogyasztása erősen összefügg a lakosság jövedelmének alakulásával, azaz a növekvő jövedelmek hatására a sportcikkek vásárlásai a jövedelem növekedésének ütemét meghaladó mértékben emelkednek. Emellett az is látható, hogy a javuló jövedelmi hely- 
zetủ lakosság célja, hogy csökkenteni tudja a munkavégzésre szolgáló idejét, a felszabaduló szabadidőben pedig különböző aktivitásokat végezzen, így például sportolhasson, ami egyértelmủen indukálja a sportcikkekre fordított kiadások emelkedését (Paár, 2009). A jelenség további elemzése során megállapítható, hogy a sportolással és a sportoláshoz szükséges eszközök, felszerelések és ruházatok vásárlásával a fogyasztók szükségleteket elégítenek ki. A fogyasztók aktuális helyzete ebben az esetben eltér attól, amit ideálisnak tekintenek - például hiányzik nekik a sport, nem rendelkeznek valamilyen olyan sportoláshoz szükséges eszközzel, amelyekre szükségük lenne -, de késztetésük van helyzetük javítására, vagyis megfelelő motivációval rendelkeznek arra, hogy a szükségletüket kielégítsék (Bakacsi, 2015; Dajnoki-Héder, 2017). Ez a sporteszközök, sportszerek és sportruházatok fogyasztása szempontjából egyben azt is feltételezi, hogy a fogyasztóknak anyagilag is van lehetőségük a szükségesnek tartott beruházások megvalósítására.

A különböző sportszerek, sporteszközök és sportruházatok vásárlói maguk is fogyasztói döntéseket hoznak akkor, amikor az egyes termékek megvásárlásáról döntenek, illetve akkor is, amikor a piacon elérhető kínálatból kiválasztják a számukra leginkább megfelelő terméket. A vásárlók fogyasztói magatartása erősen függ saját tapasztalataiktól, emellett gyakorta kapcsolódik különböző érzelmekhez is. A különböző fogyasztói, vásárlói csoportokhoz eltérő módon kell közelíteniük a kereskedőknek annak érdekében, hogy sikerrel értékesíthessék termékeiket (CarpenterFairhurst, 2005). A szakirodalom széleskörü konszenzusa szerint a különböző márkákhoz való fogyasztói hűség alapja mindenekelőtt a bizalom. A fogyasztó korábbi tapasztalatai alapján rendelkezik egyfajta benyomással az adott gyártó termékeit illetően, ami megfelel az ő saját elvárásainak (Carpenter-Fairhurst, 2005; Noble et al., 2009). A fogyasztói döntés alapja tehát az a bizalom, hogy az újabb termék is kielégíti majd a fogyasztói elvárásokat. A márkahűség a piacon lévő egyes forgalmazóknak ilyen módon előnyt jelenthet, hiszen korábbi sikereik alapján újabb termékeik felé is bizalommal fordulnak a fogyasztók. Ugyanakkor ez egy nagy felelősséget is maga után von, hiszen az elvártaknál gyengébb teljesítmény hatására a fogyasztói bizalom megrendülhet.

Napjainkban a fogyasztás, a vásárlások egyre nagyobb hányada történik online környezetben. Az online vásárlások során is elsősorban a fogyasztói elégedettségnek van jelentősége, az elektronikus szolgáltatásokkal kapcsolatos elégedettség csak másodlagos jelentőséggel bír (Carlson-O’Cass, 2011). A márkahüség kialakítása kapcsán is komoly relevanciával bíró megállapítás szerint a meglévő vásárlók, fogyasztók megtartása mindig kevésbé költséges az új ügyfelek megszerzésénél, így az online vásárlások esetében is elsősorban arra kell törekedni, hogy növekedjen a vevői elégedettség és lojalitás (Somogyi, 2013). Az online szájreklámok jelentősége is egyre növekszik napjainkban a fogyasztói döntést befolyásoló tényezők között. Ezek között a pozitív vélemények mellett - negatívak is akadhatnak. A fogyasztói vélemények 
közlésére rendelkezésre álló fórumok száma egyre növekszik, emiatt túl sok információ áll a fogyasztók rendelkezésre. A vásárlók mérlegelni kénytelenek az egyes források szavahihetőségét a fogyasztói döntéshozatali folyamat során. Ugyanakkor az is megfigyelhető, hogy az online tereken zajló viták során az elkötelezett, márkahü fogyasztók kiállnak saját kedvenc gyártójuk vagy forgalmazójuk védelmében (MarkosKujbus-Csordás, 2016). A részletezett folyamatok természetesen a sporteszközök, sportszerek és sportruházatok kereskedelme szempontjából is kiemelt jelentőséggel bírnak, hiszen a felsorolt termékek fogyasztói általában olyan demográfiai jellemzőkkel bírnak, amelyek az online vásárlások iránt nyitott fogyasztókra is jellemzőek.

A sportszerek piaca egy rendkívül összetett gazdasági tér, melynek müködését számos körülmény befolyásolja. A sportszerpiacon sikeres sportágak jellegzetessége, hogy mind az élsport-versenysport, mind pedig tömegsport területén képviseltetik magukat (Bujdosó-Dávid, 2013). Ilyen sportágak lehetnek például a kerékpározás, a labdajátékok közül a labdarúgás, az atlétikai sportok közül a futás vagy a téli sportok közül a síelés (Faragó et al., 2018). A sportszerek, sportfelszerelések és a sportruházat piacának az élsporton, versenysporton kívül eső része két szemszögből közelíthető meg. A felsorolt termékek gyártói és forgalmazói kapcsolatba léphetnek a különböző tömegsportesemények, szabadidő-sportolási lehetőségek szervezőivel, akikkel kölcsönösen előnyös megállapodásokat köthetnek. A megállapodások alapján a sportesemények szervezői a sportszerek, sportfelszerelések és sportruházat tekintetében beszállítóként jelenhetnek meg a különböző sporteseményeken, ami jelentős marketingértékkel bír, illetve javulhat az adott márka társadalmi megítélése is. Másfelől a felsorolt termékek gyártói és forgalmazói közvetlenül a fogyasztóknak is értékesíthetnek sportszereket, sportfelszereléseket vagy sportruházatot. Ez a fogyasztói szegmens erősen kötődik a szabadidős sportolási lehetőségek köréhez, hiszen azok megléte befolyásolja a fogyasztás mértékét (Szabó, 2013). A felsorolt termékek iránti keresletet, így végső soron a gyártók és forgalmazók piaci sikerét befolyásolja a forgalmazott termékek ára, azok ár-érték aránya, minősége, a márka fogyasztók szemében betöltött értéke és a fogyasztói hűség (Szabó, 2015).

Ahhoz, hogy a különböző sportfelszerelések, sportcikkek piacáról megfelelő képet alkossunk, érdemes azt megvizsgálni, hogy kik lehetnek a felsorolt termékek potenciális fogyasztói. A felmérések alapján a férfiak hajlamosabbak többet sportolni a nőknél, a fiatalabbak jellemzően többet sportolnak az idősebbeknél, a legfeljebb kétgyermekes családok szabadidősport-részvételi hajlandósága jelentősen nagyobb a gyermektelenekénél, ugyanakkor a két gyermeknél többet nevelő háztartások esetében csökken a sportban való részvételre mutatott nyitottság, hajlandóság. Felmérések szerint a magasabb iskolai végzettséggel rendelkezők hajlamosabbak aktívan bekapcsolódni a sportolásba, és hasonló sajátossággal bírnak a magasabb jövedelemmel rendelkezőkről is (András, 2006). Ez utóbbi két faktor egyébként is igen szoros össze- 
függésben áll, hiszen az OECD adatfelmérései évről évre igazolják, hogy a munkaerőpiac a világ csaknem összes országában magasabb jövedelemmel honorálja a magasabb iskolai végzettséget, illetve az ilyen úton megszerezhető frissebb, aktuálisabb többlettudást (OECD, 2018). A családok sportok iránti nyitottságát jelentősen befolyásolja a gyermekek érdeklődése. Amennyiben egy-egy gyermek érdeklődni kezd valamely sportág iránt, az az egész család sportok iránti érdeklődését, nyitottságát képes befolyásolni, vagyis a gyerekek érdeklődése kihat a családok fogyasztási szerkezetére is, ami a sporteszközök, sportfelszerelések és sportruházatok vásárlására is kihat (Harrington, 2015).

A különböző sporteszközök és sportfelszerelések fejlesztése során azok gyártói a legmodernebb elérhető technológiával igyekeznek dolgozni. Remek példa erre a különböző sporteszközök és sportfelszerelések fejlesztése során alkalmazott nanotechnológia példája, amellyel az utóbbi évek során kerékpárgyártók, golffelszerelések gyártói és tenisztermékek fejlesztői is éltek. A gyártók meggyőződése szerint a legfejlettebb technológia alkalmazásával az általuk gyártott termékek jellemzői jobbak lesznek a piaci versenytársak által kínált termékekénél, vagyis maguk a termékek könynyebbek, erősebbek, dinamikusabbak lesznek. Ezáltal a modern eszközök alkalmazásával a sport által jelentett versengésben legális előnyhöz lehet jutni a versenytársakhoz képest. Az eszközök teljesítményének javulásában rejlő lehetőségek és előnyök a magasan képzett fogyasztók számára is egyértelműek, akik nagyobb fizetési hajlandóságot mutatnak olyan termékek vásárlása iránt, amelyek használatától saját egészségük hatékonyabb védelmét feltételezik. A legfrissebb technológia elterjesztését jellemzően különböző versenysportok körében kezdték meg az eszközök gyártói, ahol ismert sportolókat kértek fel az új eszközök alkalmazására. Ilyen módon a modern technológia ismertté válik, és elterjed a fogyasztók szélesebb körében is (Anis et al., 2017). Ugyanakkor az is megfigyelhető, hogy az elérhető csúcstechnológiák egyre nagyobb arányban jelennek meg olyan termékekben is, amelyekben a fogyasztók nem használják ki a termékben rejlő valamennyi lehetőséget. Remek példa erre a himalájai hegymászásra kifejlesztett, kimagasló hőszigetelő képességgel bíró kabátok megjelenése kimondottan városi felhasználási környezetben. Ilyen esetekben a fogyasztó részben azért vállalja a magasabb vételár megfizetését, mert a kiválasztott termék által hordozott üzenet, amely szerint a használó és maga a termék is mindenre készen áll, vonzó a számára (Hall, 2016). Ugyanakkor a technológiai innovációk gyakorlati és tömeges alkalmazása a termelés során csak akkor lehet sikeres, ha az adott technológia már a gyártó szervezetben is megfelelő módon leképeződik. Az innovációk túl korai tömeggyártásba küldése negatív hatással is lehet a gyártók termelésére (Grindley, 1991).

A sporteszközök, sportfelszerelések és sportruházatok hozzáférhetősége nagyban függ az adott fogyasztó anyagi helyzetétől. A gazdagabb fogyasztók több sporttal kapcsolatos kiadást tudnak eszközölni, ami a sportok eszközigényének kielégítésében is 
szerepet játszik, míg a kevésbé tehetős fogyasztók sportra fordítható kiadásai is korlátozottak. A sporteszközök kereskedelmének és gyártásának fenntarthatósága szempontjából is fontos, ugyanakkor a sporteszközökhöz való hozzáférés szempontjából is kiemelkedő jelentőséggel bír a használt termékek kereskedelme. A korábban csak használteszköz-boltokban, bolhapiacokon, garázsvásárokon elérhető termékek kereskedelmét az internet és az online piacterek megjelenése teljesen átalakította, sokkal szabadabbá és elérhetőbbé téve ezzel az akár költséges eszközök megvásárlását is a szerényebb jövedelemmel rendelkező emberek számára is (Guillen-Royo-Wilhite, 2015). Az anyagi lehetőségek befolyásolják a helyszíni sportfogyasztást is, hiszen a legnépszerűbb sportágak legnagyobb világversenyei egyre kevésbé elérhetőek az átlagos nézők számára - legalábbis a helyszínen (Nauright-Pope, 2016), azonban a telekommunikációs forradalom hatására az ilyen sportesemények globális elérhetősége javulni tudott.

\section{Sporteszközök fogyasztása az Európai Unióban}

Az Európai Unió tagállamaiban végzett sporttevékenységek egy jelentős részéhez a sportolóknak különböző sporteszközökre, sportkellékekre és speciális sportruházatokra van szüksége. Az ilyen termékek gyártása, forgalmazása és kereskedelme egyre nagyobb gazdasági jelentőséggel bír az Unió egészét tekintve, illetve egyes tagállamok nemzetgazdaságát vizsgálva is. A sporteszközök és sportkellékek uniós szintü kereskedelmével kapcsolatos statisztikák két különböző szinten mérik a vizsgált termékek forgalmát. A jelenség vizsgálható ugyanis az Európai Unión belüli, tagállamok közötti kereskedelmi folyamatként is, de ugyanennek a forgalomnak komoly relevanciája van az Európai Unió és a nem uniós tagállam harmadik országok közötti kereskedelem viszonylatában is. Az EUROSTAT vonatkozó adatközlésében a COMEXT kereskedelmi adatokra vonatkozó adatbázisa az Európai Unió tagállamai mellett az Európai Szabadkereskedelmi Társulás, vagyis az EFTA tagállamainak vonatkozó adatait és az uniós tagságra pályázó tagjelölt országok megfelelő adatait is tartalmazza (Eurostat, 2018).

Az alábbiakban bemutatjuk egyfelől az Európai Unión kívülre irányuló sporteszköz, sportszer és sportruházat exportját euróértékben kifejezve, az Unió 28 tagállamában, termékcsoport szerinti bontásban. Másfelől pedig az Európai Unión kívülről származó sporteszközök, sportszerek és sportruházat importját is bemutatjuk az Európai Unió 28 tagállamát tekintve, termékcsoport szerinti bontásban. A statisztikai adatközlések a sportfelszereléseket, sporteszközöket és sportruházatokat az alábbi csoportbontás szerint közlik: síelés és kapcsolódó felszerelések; korcsolyák; csónakok és vízisport-felszerelések; golffelszerelések; ütős sportágak (tenisz és tollaslabda) felszerelései; labdák; torna-, atlétika- és úszófelszerelések; horgászfelszerelések; kerékpárok; 
ejtőernyők; sportruházat, sportcipők; végül a sportlövészeti felszerelések (Eurostat, 2018).

Az Eurostat (2018) adatközlése szerint az Európai Unió tagállamain kívülre irányuló sporteszköz-, sportruházat- és sportszerkivitel legnagyobb része, mintegy kétharmada $(65,6 \%)$ a csónakok és vízisport-felszerelések piacán jelent meg. Ennek alapján egyáltalán nem túlzó azt állítani, hogy ezek a vízi sportok a teljes uniós sportszer- és sporteszköz-gyártó ipar működése szempontjából kiemelt jelentőséggel bírnak.

A második legnagyobb szeletet az európai uniós sporteszköz, sportszer és sportkellék kiviteléből a teljes vizsgált exportforgalom 10,6\%-ával a torna-, atlétika- és úszófelszerelések kategóriája hasította ki. A harmadik és negyedik legjelentősebb sporteszköz- és sportszerkivitel a síeléshez kapcsolódó különböző termékek piacán (5,8\%) és a sportoláshoz használt különböző cipők kereskedelmében (5,6\%) jelentkezett (Eurostat, 2018). A télisportok ilyen előkelő helyezése az exportált termékek piacán nem meglepő, hiszen az Alpok térsége vagy Skandinávia a télisportok legjelentősebb centrumai között szerepel, emellett az is látható, hogy azok müvelése milyen jelentős hatást gyakorol például a teljes osztrák nemzetgazdaságra is. A következő sporteszközkiviteli kategória, a sportlőfegyverek exportja egy igen különleges piacnak tekinthető, azonban így is 3,7\%-os részesedést tudott szerezni a sporteszközök és sportszerek teljes uniós kiviteléből. A hatodik legjelentősebb sporteszköz- és sportfelszerelés-exportszegmens a kerékpárok kivitele volt, amely a teljes vizsgált uniós szegmens 2,9\%-át adta ki. Mindez egyáltalán nem meglepő, ha az európai kerékpárgyártási tradíciókra gondolunk, illetve szem előtt tartjuk a kerékpárok jelentőségét a mindennapi mobilitás biztosítása terén is. A hetedik legfontosabb kiviteli szegmens a sportruházatok exportja volt, amely a teljes uniós sportcikk-kivitel 2,2\%-át jelentette 2016-ban (Eurostat, 2018). A következő szegmens, a horgászati felszerelések kivitele a teljes sporteszközexport 1,1\%-át jelentette a vizsgált évben. A horgászat igen széles körben elterjedt kedvtelés, ami alátámasztja a felmutatott jelentős gazdasági eredményt. Sokkal szűkebb körben müvelt sportág sporteszközexportja került a kilencedik helyre: az ejtőernyők kivitele adta a teljes uniós sporteszközexport 0,6\%-át, holtversenyben a rendkívül népszerü labdatermékek exportjával és a továbbra is elitsportként értelmezhető golfeszközök kivitelével. A golfot követő helyre a - szintén elitsportként értelmezett - ütős sportok sporteszközkivitele jutott, hiszen tenisz- és tollaslabdaeszközök kiviteléből származott a teljes uniós sportszer- és sporteszközkivitel 0,5\%-a. A legkisebb, 0,3\%-os részesedést a korcsolyák kivitele hasította ki a teljes uniós sporteszköz- és sportszerexportból (Eurostat, 2018).

Az Európai Unió tagállamai harmadik országokból is jelentős mennyiségű sporteszközt, sportszert, sportfelszerelést és sportruházatot importálnak. Az export szerkezeténél sokkal diverzifikáltabb az árubehozatal összetétele, nem lehet olyan egyedüli domináns területet megjelölni, mint amilyen a kivitel esetén a csónakok és vízisport- 
felszerelések köre. A behozatal esetén a három legnagyobb részesedéssel rendelkező árucsoport együttes eredménye rendelkezik akkora piaci részesedéssel, mint amekkorával a kivitel területén a piacvezető csónak és vízisport-felszerelések bírnak. A behozatal legnagyobb részét a sportoláshoz használt különböző cipők adják, amelyek együttesen a teljes importpiac 25,7\%-át teszik ki (Eurostat, 2018). Ezt követi a tornasportok, a különböző atlétikai sportok és az úszás különböző nemei által használt felszerelések piaca, ami az összesített behozatal 21,2\%-át adta a vizsgált évben. Érdekes, hogy a csónakok és vízisport-felszerelések nemcsak az Európai Unió kivitelében, hanem behozatalában is jelentős szerepet játszanak, hiszen a teljes importpiac 20,6\%át ez a termékcsoport adta. A kerékpárok behozatala is jelentős volt, hiszen a teljes sporteszköz- és sportszerbehozatal 9,7\%-át ez a szegmens tette ki 2016-ban (Eurostat, 2018). Ezt a sportruházatok behozatala követte a vizsgált évben, ami a teljes uniós szintű sportcikk-behozatal 7,9\%-át tette ki a vizsgált évben. A sorban következő horgászati felszerelések behozatala az Európai Unió sporteszköz-importjának 3,7\%-áért volt felelős 2016-ban (Eurostat, 2018). Ez azért is előnyös, mert a kifogott halak formájában a sportolók kimagaslóan egészséges élelmiszerez is juthatnak.

A labdaimport a teljes uniós sportszerbehozatal 3,4\%-át tette ki 2016-ban, ami igazolja a labdasportok népszerűségét az Európai Unió tagállamaiban. A golffelszerelések behozatala tette ki a teljes uniós sporteszköz- és sportfelszerelés-import 2,5\%át, míg a teljes sportszerbehozatal 1,6\%-a a korcsolyák köréből került ki 2016-ban. Ezt csak kisebb mértékben múlta alul a síeléshez szükséges különböző felszerelések behozatala, amelyek a teljes uniós sportszerbehozatal 1,5\%-át adták. A legkisebb importpiaci részesedéssel az ejtőernyők $(0,6 \%)$, illetve az ütős játékok sportfelszerelései és a sportlövészet különböző fegyvernemeihez szükséges eszközök és berendezések (0,5-0,5\%) jelentették 2016-ban (Eurostat, 2018).

\section{Összefoglalás}

Cikkünkben ismertettük a sporteszközök piacának történelmi fejlődését. A sportszerek és sporteszközök a sportok kifejlődésével együtt jelentek meg, vagyis jellemzően a 19. században vagy azt követően jelentek meg azok a céleszközök, amelyek kifejezetten a testmozgás, a testedzés végzését segítették elö. Ebben az időben alakultak ki azok a szabályrendszerek, amelyek nemcsak az egyes sportok művelésének pontos módját, hanem a sportszerekre vonatkozó szabványokat is tartalmazták. Egyes sporteszközök, így például a kerékpárok gyártását illetően több mint száz évre vonatkozóan is rendelkezésre állnak statisztikai adatok, ezekből az is kiderül, hogy ezeket az eszközöket nemcsak versenysportra, hanem tömegsportra és a mobilitási kihívások orvoslására is alkalmazták. 
Ezt követően a sportszerek fogyasztásával kapcsolatos szokások változásait tekintettük át. A sportszerek vásárlása iránti nyitottság számos körülménytől függ, amelyek közül első helyen a fogyasztók anyagi helyzetét kell megemlíteni. A sportra fordítható pénz mennyisége eleve meghatározza, hogy az egyes sportágakat kik fogják művelni: vannak olyan sportágak, amelyek napjainkig is megőrizték exkluzív, olykor arisztokratikus jellegüket, míg más sportok napjainkra széles körben elterjedtek - az előbbieket jellemzően költségesebb, az utóbbiakat általában olcsóbb művelni. A sportszerek vásárlása iránti nyitottságot további körülmények is befolyásolják, mint például a családszerkezet, a nem, az életkor vagy a lakóhely. Az utóbbi évek, évtizedek során azt is tapasztalhattuk, hogy a sporteszközök fogyasztói piaca jelentős változásnak indult: a kereskedelmi forgalom egyre nagyobb része zajlik interneten, ahol sokkal több véleményt is olvashatnak a potenciális fogyasztók az egyes termékekről, márkákról. Ebből kifolyólag a márkahűség, a lojalitás kiépítése minden korábbinál fontosabbá vált a nagy sporteszköz- és sportszergyártók számára.

Végül cikkünkben az Európai Unió sporteszköz- és sportszerpiacát elemeztük. Noha az egyes uniós tagállamok között jelentős eltérés mutatható ki abban a tekintetben, hogy hol mely sportágak igazán népszerűek, a sportipar világban betöltött egyre jelentősebb szerepe az Európai Unió egészének gazdaságát tekintve is megjelenik. Vannak olyan sporteszközök, amelyek elterjedése és jelentősége attól függ, hogy az egyes országokban mennyire jellemző azok használata, míg vannak általánosságban is népszerű termékkörök. Az első csoportra jó példa a Skandináviában vagy Ausztriában népszerủ télisporteszközök köre, míg az utóbbira remek példát jelentenek a kerékpárok.

Összességében látható, hogy a hosszú, évszázados történelmi fejlődés és a jelenséget övező társadalmi változások hatására a sport napjainkra megkerülhetetlen jelenséggé vált - és nemcsak egészségügyi és versenyzési, hanem gazdasági szempontból is. A sportok elterjedésével és népszerűvé válásával a művelésükhöz szükséges eszközök és speciális sportszerek gyártása is egyre nagyobb szerephez jutott. Az Európai Unió jelentősége ezen a piacon pedig megkérdőjelezhetetlen. 


\section{Köszönetnyilvánítás}

A publikáció elkészítését az EFOP-3.6.2-16-2017-00003 számú projekt támogatta. A projekt az Európai Unió támogatásával, az Európai Szociális Alap társfinanszírozásával valósult meg.

\section{Hivatkozott források}

[1.] András K. (2006): A szabadidősport gazdaságtana. 75. számú műhelytanulmány. Budapes,t Budapesti Corvinus Egyetem Vállalatgazdaságtan Intézet.

[2.] Anis, M. - AlTaher, G. - Sarhan, W. - Elsemary, M. (2017): Nanovate. Commercializing Disruptive Nanotechnologies. Cham, Springer. DOI: 10.1007/978-3-319-44863-3

[3.] Bácsné Bába É. - Fenyves V. - Szabados Gy. - Pető K. - Bács Z. - Dajnoki K. (2018): Sport Involvement Analysis in Hungary, in the North Great Plain Region. Sustainability, Vol. 10. No. 5. DOI:10.3390/su10051629.

[4.] Bácsné Bába É. - Fenyves V. - Szabados Gy. - Dajnoki K. - Müller A. Bács Z. (2019): A sportágazat nemzetgazdasági jelentőségének vizsgálata beszámoló adatok alapján 2014-2016-os időszakban. Jelenkori Társadalmi és Gazdasági Folyamatok, Vol. 13. No. 3-4. 93-103. o.

[5.] Bakacsi Gy. (2015): A szervezeti magatartás alapjai. Budapest, Semmelweis Kiadó.

[6.] Bourdieu, P. (1978): Sport and social class. Social Science Information, Vol. 17. No. 6. 819-840. o.

[7.] Bujdosó Z. - Dávid L. (2013): Extreme sports and other activities in tourism with special regard to the Mátra Mountain. Journal of Physical Education And Sport, Vol. 13. No. 1.39-45.p.

[8.] Bujdosó Z. - Györki, M. (2011): A biztonság szerepe a turizmusfejlesztésben. Acta Carolus Robertus, 1. évf. 2. sz. 45-55. o.

[9.] Carlson, J. - O'Cass, A. (2011): Developing a framework for understanding e-service quality, its antecendents, consequences and mediators. Managing Service Quality, Vol. 21. No.3. 264-286. o.

DOI: $10.1108 / 09604521111127965$

[10.] Carpenter, J. M. - Fairhurst, A. (2005): Consumer shopping value, satisfaction, and loyalty for retail apparel brands. Journal of Fashion Marketing and Management, Vol. 9. No. 3. 256-269. o.

DOI: $10.1108 / 13612020510610408$ 
[11.] Dajnoki K. - Halász P. - Kőmíves P. M. - Szabados Gy. N. - Bácsné Bába É. (2019): Airsoft kilátások: sport és a szervezeti oldal. Hadtudomány, 29. évf. E-szám 105-115. o.

[12.] Dajnoki K. - Héder M. (2017): „Új szelek fújnak” - a HR válasza a globalizáció és a változás kihívásaira. Hadtudomány, 27. évf. E-szám 84-93. o.

[13.] Detre K. (2013): Testkultúra, életreform, egészség, szépség, szabadidő. In: Beke L. - Németh A. - Vincze G. (szerk.): MOZDULAT - Magyar mozdulatművészet a korabeli társadalom és művészet tükrében. Budapest, Gondolat Kiadó. 84-96. o.

[14.] Dunning, E. (2002): A sport mint férfiaknak fenntartott terület: megjegyzések a férfi identitás társadalmi gyökereiről és változásairól. Korall, 7-8. sz. 140-154. o.

[15.] Eurostat (2018): Sport statistics 2018 edition. Eurostat's sport statistics harmonised EU-level sport data. Letöltés dátuma: 2020. 03. 28. forrás: https://ec.europa.eu/eurostat/documents/4031688/8716412/KS-07-17-123-ENN.pdf/908e0e7f-a416-48a9-8fb7-d874f4950f57

[16.] Faragó B. - Konczosné Szombathelyi M. - Béki P. (2018): A világ sportpiacának dinamikusan fejlődő területei a 21. század világgazdasági és világpolitikai folyamataiban. Multidiszciplináris Kihívások Sokszínű Válaszok, 2. 94-125. o.

[17.] Grindley, P. (1991): Turning technology into competitive advantage. Business Strategy Review, Vol. 2. No. 1. 35-48. p.

DOI: $10.1111 / j .1467-8616.1991 . t b 00146 . x$

[18.] Guillen-Royo, M. - Wilhite, H. L. (2015): Wellbeing and sustainable consumption. In: Glatzer, W. - Camfield, L. - Møller, V. - Rojas, M. (Eds.): Global handbook of quality of life. Dordrecht, Springer. 301-316. p.

DOI: $\underline{10.1007 / 978-94-017-9178-6 \_13}$

[19.] Gyömörei T. (2015): Magán és közfinanszírozás a sportban. In: Ács P. (szerk.): Sport és gazdaság. Pécs, Pécsi Tudományegyetem Egészségtudományi Kar. 94-160. o.

[20.] Hall, A. (2016): Sports innovation: new models and future potential. In: Southgate, D. F. L. - Childs, P. R. N. - Bull, A. M. J. (Eds.): Sports innovation, technology and research. London, World Scientific. 115-125 p. DOI: $\underline{\text { 10.1142/9781786340429_0007 }}$

[21.] Hardy, S. (1986): Entrepreneurs, organizations, and the sport marketplace: subjects in search of historians. Journal of Sport History, Vol. 13. No. 1. 14-33. p.

[22.] Harrington, M. (2015): Practices and meaning of purposive family leisure among working- and middle-class families. Leisure Studies, Vol. 34. No. 4. 471-486. p. DOI: $\underline{10.1080 / 02614367.2014 .938767}$ 
[23.] Harrison, A. E. (1969): The competetiveness of the British cycle industry 1890-1914. The Economic History Review, Vol. 22. No. 2. 287-303. p. DOI: $\underline{10.2307 / 2593772}$

[24.] James, M. (2017): Sports law. Third edition. London, Macmillan International - Red Globe Press.

[25.] Markos-Kujbus É. - Csordás T. (2016): Fogyasztók a vállalatok ellen? Negatív online szájreklám virtuális kereskedelmi közösségekben. Médiakutató, 16. évf. 3-4. sz. 157-168. o.

[26.] Nauright, J. - Pope, S. (2016): The twenty-first-century SportrWorld: global markets and global impact. Sport in Society, Vol. 20. No. 12. 1-4. p.

[27.] Noble, S. M. - Haytko, D. L. - Phillips, J. (2009): What drives college-age generation y consumers? Journal of Business Research, Vol. 62. No. 6. 617628. p. DOI: $10.1016 /$ j.jbusres.2008.01.020

[28.] OECD (2018): Education at a glance 2018: OECD indicators. Párizs, OECD Publishing.

[29.] Paár D. (2009): A magyar sportfogyasztás dinamikája. In: Mészáros J. Mónus A. - Bendiner N. (szerk.): Magyar Sporttudományi Szemle. VII. Országos Sporttudományi Kongresszus. Konferencia CD. Budapest, Magyar Sporttudományi Társaság.

[30.] Somogyi I. (2013): Az online fogyasztói elégedettségmérés hatása a vállalatok versenyképességére. Vezetéstudomány, 44. évf. 3. sz. 49-60. o.

[31.] Szabó Á. (2013): Szabadidő-sport piacok Magyarországon. Vezetéstudomány, 44. évf. 4. sz. 18-28. o.

[32.] Szabó Á. (2015): A szabadidősport gazdasági kérdései. In: Ács P. (szerk.): Sport és gazdaság. Pécs, Pécsi Tudományegyetem Egészségtudományi Kar. 482-526. o.

[33.] Vamplew, W. (2018): Products, promotion and (possibly) profits. Sports entrepreneurship revisited. Journal of Sports History, Vol. 45. No. 2. sz. 183-201. o. 


\section{Szerzők:}

\section{Harangi-Rákos Mónika}

egyetemi docens

Debreceni Egyetem Gazdaságtudományi Kar rakos.monika@econ.unideb.hu

\section{Nagy Adrián Szilárd}

egyetemi docens

Debreceni Egyetem Gazdaságtudományi Kar nagy.adrian@econ.unideb.hu

\section{Pfau Christa}

egyetemi docens

Debreceni Egyetem Gazdaságtudományi Kar pfau.christa@econ.unideb.hu

\section{Müller Anetta}

egyetemi docens

Debreceni Egyetem Gazdaságtudományi Kar muller.anetta@econ.unideb.hu

\section{Szabados György Norbert}

egyetemi docens

Debreceni Egyetem Gazdaságtudományi Kar szabados.gyorgy@econ.unideb.hu

Bácsné Bába Éva

egyetemi tanár

Debreceni Egyetem Gazdaságtudományi Kar bacsne.baba.eva@econ.unideb.hu 